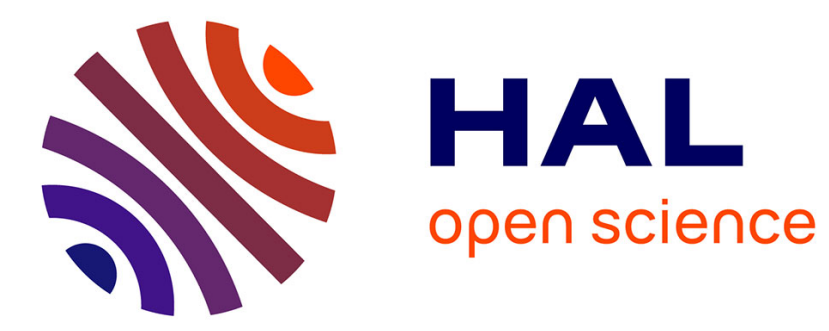

\title{
Specific surface area, density and microstructure of frost flowers
}

Florent Domine, Anne-Sophie Taillandier, William R. Simpson, Ken Severin

\section{To cite this version:}

Florent Domine, Anne-Sophie Taillandier, William R. Simpson, Ken Severin. Specific surface area, density and microstructure of frost flowers. Geophysical Research Letters, 2005, 32 (L13502), 1 à 4 p. 10.1029/2005GL023245 . insu-00374160

\section{HAL Id: insu-00374160 https://hal-insu.archives-ouvertes.fr/insu-00374160}

Submitted on 19 Feb 2021

HAL is a multi-disciplinary open access archive for the deposit and dissemination of scientific research documents, whether they are published or not. The documents may come from teaching and research institutions in France or abroad, or from public or private research centers.
L'archive ouverte pluridisciplinaire HAL, est destinée au dépôt et à la diffusion de documents scientifiques de niveau recherche, publiés ou non, émanant des établissements d'enseignement et de recherche français ou étrangers, des laboratoires publics ou privés. 


\title{
Specific surface area, density and microstructure of frost flowers
}

\author{
Florent Domine, ${ }^{1,2}$ Anne Sophie Taillandier, ${ }^{1,2,3}$ William R. Simpson, ${ }^{1,4}$ and Ken Severin ${ }^{5}$ \\ Received 15 April 2005; revised 17 May 2005; accepted 6 June 2005; published 9 July 2005.
}

[1] Frost flowers often grow on new sea ice. They are thought to have a high specific surface area (SSA) that provides sites for heterogeneous reactions. We have measured the SSA of frost flowers using $\mathrm{CH}_{4}$ adsorption at $77 \mathrm{~K}$ and obtained a value of $185(+80-50) \mathrm{cm}^{2} / \mathrm{g}$, much lower than inferred by others. Their density is $0.02 \mathrm{~g} / \mathrm{cm}^{3}$. We calculate that the total surface area of frost flowers is $1.4 \mathrm{~m}^{2}$ per $\mathrm{m}^{2}$ of ice surface, so that they do not increase the ice surface area significantly. Their role as sites for enhanced heterogeneous reactions should be reconsidered. Frost flowers also commonly grow on fresh water and the saline brine seen on young sea ice is not necessary for their growth. Photo- and electro-micrographs reveal hollow and concave structures, typical of very fast growing crystals. The brine that wicks up frost flowers considerably perturbs their growth. Citation: Domine, F., A. S. Taillandier, W. R. Simpson, and K. Severin (2005), Specific surface area, density and microstructure of frost flowers, Geophys. Res. Lett., 32, L13502, doi:10.1029/2005GL023245.

\section{Introduction}

[2] Frost flowers (FF) are delicate ice crystals that often form on the surface of young sea ice [Perovich and RichterMenge, 1994]. A highly saline brine also forms on young sea ice and wicks up the FF, leading to FF salinities of up to $115 \mathrm{~g} / \mathrm{kg}$ [Rankin et al., 2002]. The fragile FF can be windblown and supply sea salt aerosol to the atmosphere and the marine and coastal snowpacks. The interest for FF has grown recently because of their possible role in supplying bromine compounds to the atmosphere, thus leading to ozone and mercury depletion events in polar regions [Kaleschke et al., 2004]. Rankin et al. [2000, 2002, and references therein] and Wolff et al. [2003], based on the observation that sea salt from frost flowers was fractionated due to mirabilite precipitation, also suggested that they may be the main wintertime source of sea salt to the Antarctica. This has important implications for ice core interpretation and our understanding of past atmospheric circulation around Antarctica [Rankin et al., 2002]. Finally, Rankin et al. [2002] estimated that FF had a total surface area (TSA,

\footnotetext{
${ }^{1}$ Geophysical Institute, University of Alaska Fairbanks, Fairbanks, Alaska, USA.

${ }^{2}$ Now at Centre National de la Recherche Scientifique, Laboratoire de Glaciologie Geophysique de l'Environnement, Saint Martin d'Hères, France.

${ }^{3}$ International Arctic Research Center, University of Alaska Fairbanks, Fairbanks, Alaska, USA.

${ }^{4}$ Department of Chemistry and Biochemistry, University of Alaska Fairbanks, Fairbanks, Alaska, USA

${ }^{5}$ Department of Geology and Geophysics, University of Alaska Fairbanks, Fairbanks, Alaska, USA
}

Copyright 2005 by the American Geophysical Union. 0094-8276/05/2005GL023245 as defined by Dominé et al. [2002]) in the range 50$1000 \mathrm{~m}^{2}$ per $\mathrm{m}^{2}$ of ice surface, "probably nearer the upper limit", and suggested that they provide sites for enhanced exchanges and chemical reactions [Rankin et al., 2002].

[3] To obtain their estimate of the TSA of FF, Rankin et al. inferred values of the specific surface area (SSA, i.e. the surface area per unit mass) of FF in the range 0.2 to $2 \mathrm{~m}^{2} / \mathrm{g}$. However, a recent set of 176 measurements of the SSA of snow by Legagneux et al. [2002] has found a maximum value of $0.15 \mathrm{~m}^{2} / \mathrm{g}$, observed for fresh dendritic snow. Our observations of frost flowers during several Arctic trips suggested to us that their SSA could not be greater than that of dendritic snow. We have therefore measured the SSA of FF in Alaska, using the method of Legagneux et al. [2002] and taken optical and electronic micrographs to observe their microstucture. We have also observed FF on lake and river ice in Alaska, which constrains their formation mechanism. Finally, we have measured the density of FF in Spitsbergen.

\section{Experimental}

[4] The SSA of FF was measured using $\mathrm{CH}_{4}$ adsorption at $77 \mathrm{~K}$ [Legagneux et al., 2002]. Briefly, the adsorption isotherm of $\mathrm{CH}_{4}$ on the FF sample was recorded at $77 \mathrm{~K}$. A B.E.T. mathematical treatment was used to extract the SSA. We looked for FF near Barrow, Alaska. Success commanded that we be at Barrow with liquid $\mathrm{N}_{2}$ when FF formed. A lead opened in the sea ice and FF did form before the liquid $\mathrm{N}_{2}$ arrived, but did not reform during our 18 days of presence with the liquid $\mathrm{N}_{2}$. We therefore drilled large holes in the sea ice to expose sea water, let it freeze, and let the frost flowers grow naturally on the forming ice.

[5] Ice chunks of about $70 \times 40 \mathrm{~cm}$ in surface area and $70 \mathrm{~cm}$ deep were cut off the $1.7 \mathrm{~m}$ thick sea ice with a saw at $71^{\circ} 20.363^{\prime} \mathrm{N}, 156^{\circ} 40.484^{\prime} \mathrm{W}$. Further drilling reached sea water, which filled the holes. Plastic pans $60 \times 40 \mathrm{~cm}$ and $15 \mathrm{~cm}$ deep were also filled with sea water, and froze overnight while the air temperature dropped to $-21^{\circ} \mathrm{C}$. The sky was clear and the wind speed was 2.1 to $3.6 \mathrm{~m} / \mathrm{s}$. The next morning, 9 April 2004, FF had formed on the frozen sea water, mostly toward the downwind edges of the holes and pans. Two types of crystals were observed: "dry" crystals where the wicking up of brine could not be observed, and "wet" crystals, whose surface appeared to be totally covered by the brine. Three glass vials were used for sampling: $\mathrm{N}^{\circ} 1$ contained a few wet $\mathrm{FF}$ for photography, $\mathrm{N}^{\circ} 2$ a few dry ones for photography. $\mathrm{N}^{\circ} 3$, intended for SSA measurements, contained the rest of the dry FF. Because the amount of FF was limited, all of the remaining dry FF were sampled, and a few nearby wet FF were also sampled. The vials were immediately immersed in liquid $\mathrm{N}_{2}$ where they remained until the measurements. Photomicrographs were taken in a cold room with a $35 \mathrm{~mm}$ SLR camera with 

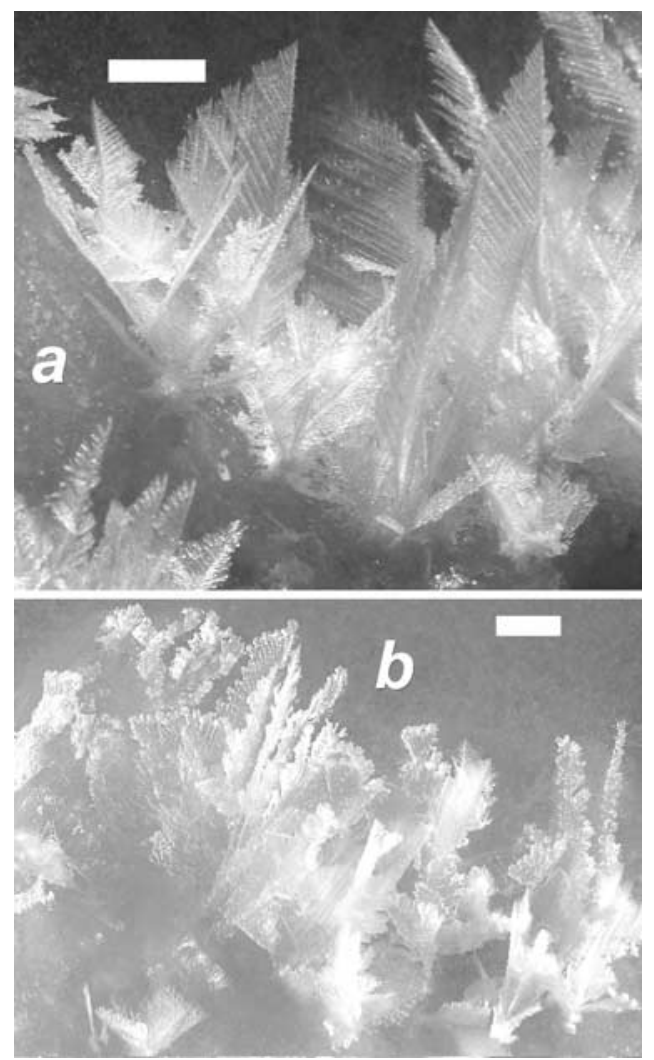

Figure 1. Frost flowers sampled for SSA measurements and photomicrographs. (a): "dry" frost flowers; (b): "wet" ones. Scale bars: $1 \mathrm{~cm}$. See color version of this figure in the HTML.

bellows. An environmental scanning electron microscope (Electroscan E2020) with a cold stage maintained around $-100^{\circ} \mathrm{C}$ was used to take electromicrographs, with $\mathrm{O}_{2}$ as a bath gas. The density of FF that formed on the east coast of Spitsbergen $\left(77^{\circ} 50.91^{\prime} \mathrm{N}, 18^{\circ} 27.63^{\prime} \mathrm{W}\right)$ was measured on 27 and 28 February 2005 by delimitating an area $15 \times 18 \mathrm{~cm}$, measuring the height of the FF, and weighing them.

[6] Frost flowers were also found on lake and river ice in various places in Alaska during leisure trips and no sampling was possible. Pictures were taken with a digital camera in macro mode.

\section{Results}

[7] Photographs of the frost flowers just before they were sampled are shown in Figure 1. FF can grow in several crystal habits, such as stellar dendrites and needles. The crystals that formed here were the more frequent stellar dendrites, similar to those observed by others [Perovich and Richter-Menge, 1994; Martin et al., 1995; Rankin et al., 2002; Kaleschke et al., 2004]. Some of the wet frost flowers show "fuzzy" edges (Figure 1b) whose aspect were reminiscent of riming on dendritic snow crystals [e.g., Cabanes et al., 2002]. Photomicrographs of dry FF are shown in Figure 2. The structure of these frost flowers is similar to that of a dendrite of atmospheric dendritic crystals [e.g., Wergin et al., 1996; Cabanes et al., 2002; Libbrecht and Rasmussen, 2003], but they are about 10 times as large and have more secondary dendrites. The tips of the dendrites can form either flat faces or rounded shapes (Figure 2). Flat faces indicate rapid growth and are observed in many precipitating crystals and in crystals metamorphosing rapidly under a high temperature gradient [Wergin et al., 1996; Dominé et al., 2003]. Rounded shapes are seen on slow growing crystals, sublimating crystals [Dominé et al., 2003], or on crystals growing extremely fast [Libbrecht, 2003]. Figure $2 b$ shows that the primary dendrite and the first secondary ones have rounded shapes, very similar to those of large (thus fast growing) atmospheric crystals [Libbrecht and Rasmussen, 2003] while other secondary dendrites have facetted ends. The frost flowers grew by about $40 \mathrm{~mm}$ in about $14 \mathrm{~h}$, so that their growth rate was around $0.8 \mu \mathrm{m} / \mathrm{s}$, close to the maximum growth rate of dendritic crystals in the atmosphere $(1 \mu \mathrm{m} / \mathrm{s})$ [Pruppacher and Klett, 1978]. The rounded shapes here are then due to very fast growth rates.

[8] Figure 3 shows photomicrographs of "wet" frost flowers. The brine layer that covers the crystal gives them a definitely different aspect, and smoothes out microstructures. Figure $3 \mathrm{c}$ also shows outgrowths at the end of brinecovered secondary dendrites. They have erratic shapes similar to rime [Dominé et al., 2001] confirming the observations of Figure 1, but rime formation is not reasonable in a cold clear night. We suggest instead that the

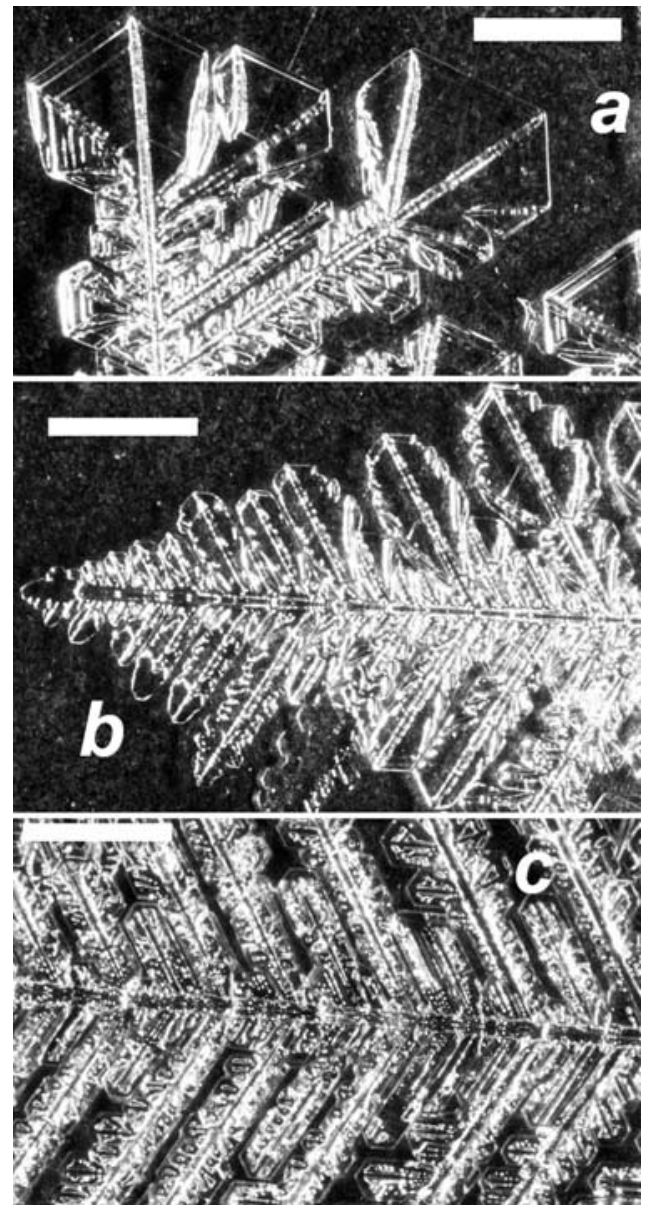

Figure 2. Photomicrographs of "dry" frost flowers. Scale bar: $1 \mathrm{~mm}$. 


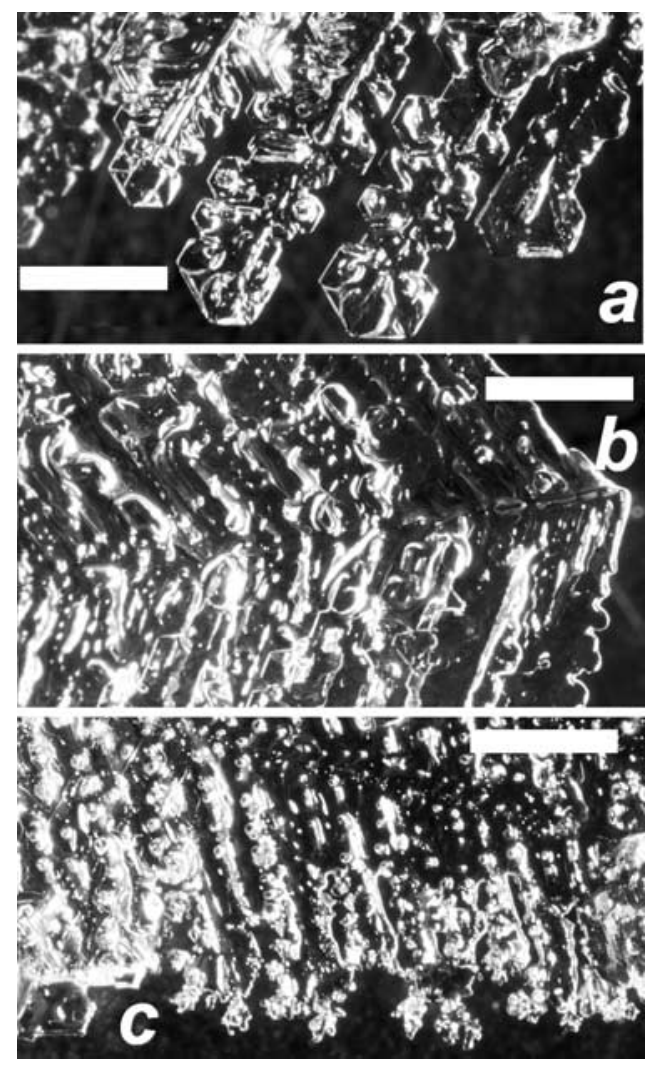

Figure 3. Photomicrographs of "wet" frost flowers. Scale bar: $1 \mathrm{~mm}$.

presence of the brine perturbed crystal growth in a major manner. Indeed, gaseous impurities significantly modify ice habit [e.g., Anderson et al., 1969], so it is reasonable to expect major modifications in the growth of crystals entirely coated with brine as growth perturbations are usually due to impurities sticking to the ice surface. The crystals showing these outgrowths were all smaller than the dry crystals, suggesting that growth of brine-covered crystals is very slow, so that to a first approximation, FF crystals stop growing when they become brine-covered.

[9] Electromicrographs of details of dry FF are shown in Figure 4. Grooves, hollows and holes are often observed. Some of the hollows (Figures $4 \mathrm{c}$ and $4 \mathrm{~d}$ ) are similar to those seen in depth hoar and surface hoar crystals [Dominé et al., 2003]. Such concave shapes are seen when fast crystal growth is limited by the gas phase diffusion of water molecules [e.g., Dominé et al., 2003, and references there- in]. Stronger depletion of molecules near the center of the faces promotes hole formation. Larger sizes increase this effect, which is expected to be often observed on FF crystals.

[10] FF were observed frequently on fresh water in Alaska. The pictures in Figure 5 were taken on Fossil creek $\left(65^{\circ} 34.0^{\prime} \mathrm{N}, 147^{\circ} 26.9^{\prime} \mathrm{W}\right)$ on 15 March 2004. Overflow water froze overnight and $\mathrm{FF}$ had grown on the newly formed ice during the clear and cold $\left(\mathrm{T}<-15^{\circ} \mathrm{C}\right)$ night. These dendritic FF are identical to those observed on sea ice by us and others. FF of the needle type were seen on Smith Lake $\left(64^{\circ} 51.9^{\prime} \mathrm{N}, 147^{\circ} 52.1^{\prime} \mathrm{W}\right)$ on 25 October 2003. Perovich and Richter-Menge [1994] observed that on forming sea ice, after a brine had appeared on the surface, small ice bumps a few $\mathrm{mm}$ in size formed on the surface. They deduced that both the surface brine and the ice bumps were critical to FF growth, with the brine acting as a source of additional water vapor and the bumps as nucleation site. The frequent observation of FF on fresh water show that the brine is not necessary for their formation. The bumps are needed because FF cannot nucleate on the liquid brine.

[11] The SSA of the FF in vial $\mathrm{N}^{\circ} 3$ was measured twice, with values of 166 and $203 \mathrm{~cm}^{2} / \mathrm{g}$. Legagneux et al. [2002] mention that the reproducibility of the method is $6 \%$. This is not verified here because there were only $6.3 \mathrm{~g}$ of FF, and the surface area of the sample was thus about $0.1 \mathrm{~m}^{2}$, while typical samples have $1 \mathrm{~m}^{2}$ of surface area. This accounts for the lower reproducibility. Furthermore, the brine on the few wet FF in the sample added mass and reduced the SSA, and this produced a negative systematic error, leading to an asymetric error bar. We thus conclude that the SSA of our FF was $185(+80,-50) \mathrm{cm}^{2} / \mathrm{g}$.

[12] FF in Spitsbergen were seen at least 24 hours after their formation. They were all brine-covered ("wet") and formed discontinuous patched 10 to $30 \mathrm{~cm}$ in diameter, about $2 \mathrm{~cm}$ thick, that covered about $25 \%$ of the ice surface. The 4 density measurements yielded values of $0.012,0.018$, 0.021 and $0.028 \mathrm{~g} / \mathrm{cm}^{3}$. These measurements have an accuracy better than $20 \%$, and the variability is ascribed to the variability in sample structure, readily visible on the site. The density for these "wet" FF is then taken as 0.02 . Dry FF are necessarily lighter, probably in the range 0.01 to 0.015 , as frequently seen for fresh dendritic snow [Cabanes et al., 2002, and unpublished results].

\section{Discussion}

[13] The SSA measured is much lower than the estimate of Rankin et al. [2002], 2000 to $20000 \mathrm{~cm}^{2} / \mathrm{g}$. The FF used
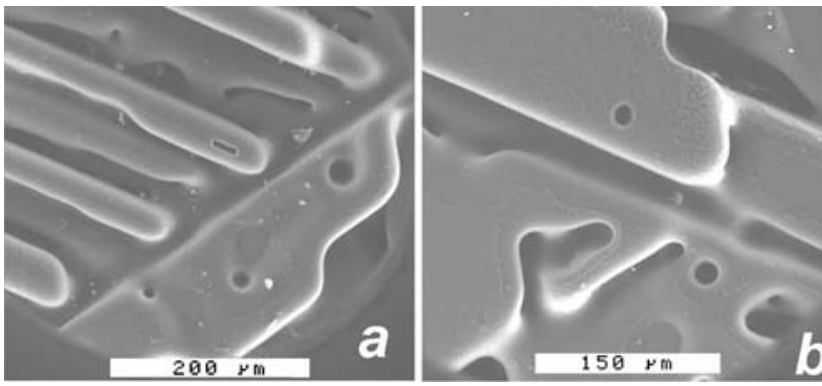
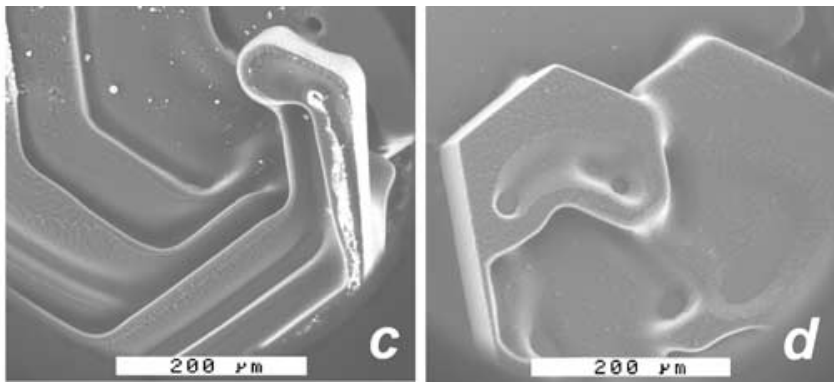

Figure 4. ESEM images of details of frost flowers. 

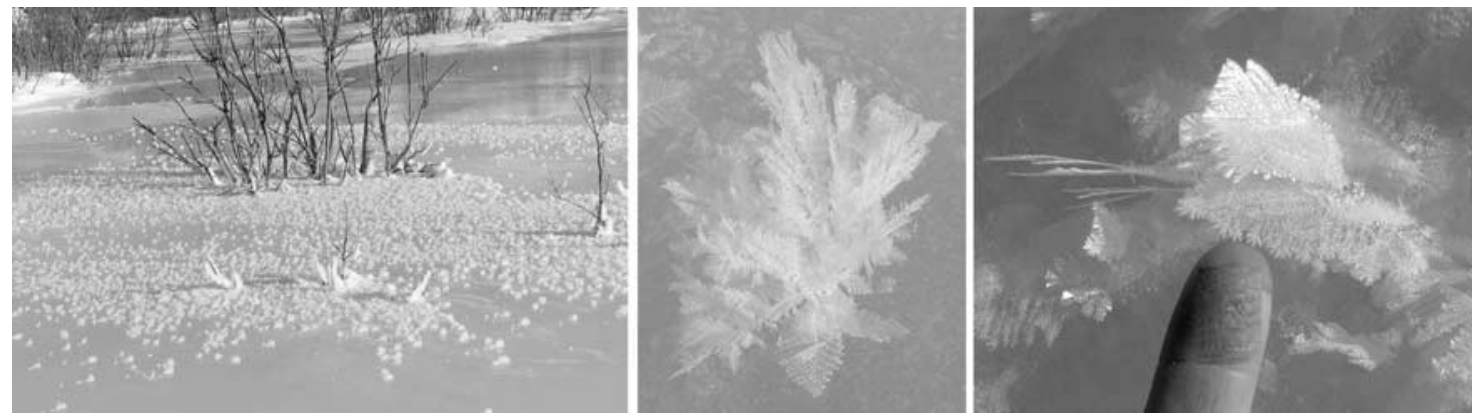

Figure 5. Photographs of frost flowers on rivers in Alaska. Width of finger: $19 \mathrm{~mm}$. See color version of this figure in the HTML.

had a microstructure similar to those of dendritic snow crystals, that have a SSA in the range $800-1500 \mathrm{~cm}^{2} / \mathrm{g}$ [Legagneux et al., 2002]. Since for a given shape, SSA is inversely proportional to size and $\mathrm{FF}$ are about 10 times larger than dendritic crystals, we expect that of FF to be $80-$ $150 \mathrm{~cm}^{2} / \mathrm{g}$, consistent with our measurements of $185 \mathrm{~cm}^{2} / \mathrm{g}$. This value can be used to estimate the TSA of FF, which is the dimensionless product of SSA $\left(\mathrm{cm}^{2} / \mathrm{g}\right)$, density $\left(\mathrm{g} / \mathrm{cm}^{3}\right)$ and height of the FF layer $(\mathrm{cm})$. Since the FF in Spitsbergen covered $1 / 4$ of the surface, our estimate of the TSA of dry FF is $185 \times 0.015 \times 2 / 4=1.4 \mathrm{~m}^{2}$ per $\mathrm{m}^{2}$ of sea ice. For wet FF, Figure 4 suggests that a brine would smooth out microstructures and reduce this TSA to less than $1 \mathrm{~m}^{2}$ per $\mathrm{m}^{2}$ of sea ice. Additional measurements of SSA and density are needed to confirm this value, but it seems unlikely that FF can provide much additional surface area relative to the ice surface itself and thus have limited potential to serve as sites of enhanced exchanges and chemical reactions. With regards to the activation of $\mathrm{Br}^{-}$contained in sea salt into forms that destroy tropospheric ozone, this result supports the conclusion of Simpson et al. [2005] that this process is not likely to take place on frost flowers themselves, but may rather be faster on surfaces where sea salt coming from $\mathrm{FF}$ has been deposited. FF, because they are highly saline and are easily windblown, can be considered as a source of sea salt and $\mathrm{Br}^{-}$to the snowpack, but probably not as sites for enhanced chemical reactions.

[14] Acknowledgments. This work was supported by NSF(ATM0420205) and by funds from the Chapman chair, generously offered by Norbert Untersteiner. We thank Jeremy Miner for his efforts in sawing off the ice blocks. FD thanks Hajo Eicken for supporting part of his Barrow trip. FD was supported by CNRS, France, during his stay in Alaska. AST was supported by the French Ministry of Research and the International Arctic Research Center. The trip to Spitsbergen was supported by the French Polar Institute (IPEV).

\section{References}

Anderson, B. J., J. D. Sutkoff, and J. Hallett (1969), Influence of methyl 2-cyanoacrylate on the habit of ice crystals grown from the vapor, J. Atmos. Sci., 26, 673-674.

Cabanes, A., L. Legagneux, and F. Dominé (2002), Evolution of the specific surface area and of crystal morphology of Arctic fresh snow during the ALERT 2000 campaign, Atmos. Environ., 36, 2767-2777.
Dominé, F., A. Cabanes, A.-S. Taillandier, and L. Legagneux (2001), Specific surface area of snow samples determined by $\mathrm{CH}_{4}$ adsorption at 77 $\mathrm{K}$, and estimated by optical microscopy and scanning electron microscopy, Environ. Sci. Technol., 35, 771-780.

Dominé, F., A. Cabanes, and L. Legagneux (2002), Structure, microphysics, and surface area of the Arctic snowpack near Alert during ALERT 2000, Atmos. Environ., 36, 2753-2765.

Dominé, F., T. Lauzier, A. Cabanes, L. Legagneux, W. F. Kuhs, K. Techmer, and T. Heinrichs (2003), Snow metamorphism as revealed by scanning electron microscopy, Microsc. Res. Tech., 62, 33-48.

Kaleschke, L., et al. (2004), Frost flowers on sea ice as a source of sea salt and their influence on tropospheric halogen chemistry, Geophys. Res. Lett., 31, L16114, doi:10.1029/2004GL020655.

Legagneux, L., A. Cabanes, and F. Dominé (2002), Measurement of the specific surface area of 176 snow samples using methane adsorption at 77 K, J. Geophys. Res., 107(D17), 4335, doi:10.1029/2001JD001016.

Libbrecht, K. G. (2003), Explaining the formation of thin ice crystal plates with structure-dependent attachment kinetics, J. Cryst. Growth, 258, $168-175$.

Libbrecht, K., and P. Rasmussen (2003), The Snowflake, Winter's Secret Beauty, Voyageur, Stillwater, Minn.

Martin, S., R. Drucker, and M. Fort (1995), A laboratory study of frost flower growth on the surface of young sea ice, J. Geophys. Res., 100, $7027-7036$

Perovich, D. K., and J. A. Richter-Menge (1994), Surface characteristics of lead ice, J. Geophys. Res., 99, 16,341-16,350.

Pruppacher, H. R., and J. D. Klett (1978), Microphysics of Clouds and Precipitation, Springer, New York.

Rankin, A. M., V. Auld, and E. W. Wolff (2000), Frost flowers as a source of fractionated sea salt aerosol in the polar regions, Geophys. Res.Lett., 27, 3469-3472

Rankin, A. M., E. W. Wolff, and S. Martin (2002), Frost flowers: Implications for tropospheric chemistry and ice core interpretation, J. Geophys. Res., 107(D23), 4683, doi:10.1029/2002JD002492.

Simpson, W. R., L. Alvarez-Aviles, T. A. Douglas, M. Sturm, and F. Domine (2005), Halogens in the coastal snow pack near Barrow, Alaska: Evidence for active bromine air-snow chemistry during springtime, Geophys. Res. Lett., 32, L04811, doi:10.1029/2004GL021748.

Wergin, W. P., A. Rango, E. F. Erbe, and C. A. Murphy (1996), Low temperature S.E.M. of precipitated and metamorphosed snow crystals collected and transported from remote sites, J. Microsc. Soc. Am., 2, 99-112.

Wolff, E. W., A. M. Rankin, and R. Röthlisberger (2003), An ice core indicator of Antarctic sea ice production?, Geophys. Res. Lett., 30(22), 2158, doi:10.1029/2003GL018454.

F. Domine and A. S. Taillandier, CNRS-LGGE, BP 96, F-38402 St Martin d'Hères, France. (florent@lgge.obs.ujf-grenoble.fr)

K. Severin, Department of Geology and Geophysics, University of Alaska Fairbanks, Fairbanks, AK 99775-5780, USA.

W. R. Simpson, Geophysical Institute, University of Alaska Fairbanks, Fairbanks, AK 99775-6160, USA. 